\title{
Bolsa de professora, lugar de virtualidades
}

\author{
Teacher's bag, room of virtualities
}

\author{
Steferson Zanoni Roseiro ${ }^{1}$ \\ Nahun Thiaghor Lippaus Pires Gonçalves ${ }^{2}$ \\ Sandra Kretli da Silva ${ }^{3}$
}

\section{Resumo}

Com o objetivo de explorar como a bolsa de professora acaba por se tornar material de criação em aula, esse artigo propõe fazer das bolsas de professoras um conceito e uma ferramenta comum à vida escolar. Se uma aula é marcada por sua possibilidade de expandir mundos e de fazê-los se colidirem na criação de coletividades, o texto argumenta que a bolsa de professora carrega, justamente, artefatos culturais e virtualidades que, em seus usos, extrapolam os limites do atual. Metodologicamente, a pesquisa valeu-se das redes de conversações tecidas entre professoras e professores de duas instituições de ensino públicas do município de Vitória/ES. Conforme fez-se evidente, a bolsa de professora tem sido cada vez mais sobrecarregada e há uma grande preocupação com isso. Aumentam as cobranças e, ao mesmo tempo, tentam diminuir suas possibilidades criadouras. Todavia, conclui destacando que, apesar da materialidade da bolsa, é sempre possivel fazer das bolsas de professoras puras virtualidades.

Palavras-chave: Aula. Bolsa de professora. Virtualidade. Atual.

1 Doutorando pelo Programa de Pós-Graduação em Educação da Universidade Federal do Espírito Santo e professor da Rede Municipal de Cariacica/ES.

2 Mestre em Biotecnologia e Mestrando em Educação pela Universidade Federal do Espírito Santo.

3 Professora do Programa de Pós-Graduação em Educação da Universidade Federal do Espírito Santo

Interfaces da Educ., Paranaíba, v.11, n.32, p. 135 - 158, 2020 ISSN 2177-7691 


\begin{abstract}
Aiming to explore how the teacher's bag ends up to become creating material in a class, this essay proposes to uses the teacher's bag as a concept and a tool common to the life school. If a class is understood by its possibility of expanding worlds and making them collide creating collectivities, the text argues that the teacher's bag carries, precisely, cultural artifacts and virtualities that, when used, extrapolate the limits of the actual. Methodologically, the research applied the conversation webs sewed among teachers of two public educational institutions from the city of Vitoria/ES. As it became evident, the teacher's bag reached its overweight and there is a huge worry about it. The demand raises and, at once, they try to diminish the teacher's creating possibilities. However, it concludes highlighting that, despite the bag's materiality, it is always possible to turn the teacher's bag pure virtuality.
\end{abstract}

Keywords: Class. Teacher's bag. Virtuality. Actual.

\title{
Professora à vista!
}

Cena pública: uma mulher entra no ônibus, pede ajuda ao trocador para passar pelas roletas com o par extra de bolsas dela, passa e procura um lugar em que possa colocar suas bolsas enquanto cumprimenta e é cumprimentada pelas pessoas do transporte coletivo. Todos a conhecem, mesmo que não saibam quem ela é - as bolsas extras não enganam, ela é professora.

Quem dá aula bem sabe: não interessa se em sua escola tem armário ou não, seja na sala dos professores ou na sala de aula; nada disso importa, em algum momento, você sai carregando um par extra de bolsas cheio de artefatos culturais. Livros, lantejoulas, brinquedos, bonecas, fantoches, jogos, papel alumínio, espelho, tintas e o que mais couber - ou não! - no interior de uma bolsa a tiracolo. Para Certeau (1998), artefatos culturais são todos os produtos criados pelo homem ordinário para as suas criações 
cotidianas. O conteúdo é infinito e, por vezes, repetivel, mas, decerto, as criações são sempre da ordem do inesperado.

É claro, que nos armários sempre terão muitos e muitos outros artefatos, daqueles que são enviados para as professoras fazerem "usos"1 (CERTEAU, 1998) na implementação dos currículos, como tantos outros que elas vão usando e guardando para outras virtualidades. Afinal, se fosse já previsto, se já fosse bem "amarradinho", estaria no armário ou seria pedido na escola, via diretora, coordenadora, ou sabe-se lá mais o que.

Não, o problema é que essas invencionices demandam de nós a vida no agora, a vida cheia de acontecimentos e de folia. É a professora que, estudando baleias com sua turma, descobre que sua tia tem uma boia em formato de orca. Pouco importa para ela e as crianças a orca ser um parente de golfinhos, naquele momento, o que sai da bolsa é uma baleia prestes a nascer após o sopro de vida de muitos professores e crianças. É a professora que, todo dia, anda com um carrinho de feira pela escola com um monte de papelão, descartáveis, recicláveis e todas as outras quinquilharias penduradas que ela consegue encontrar. "Olha, eu já nem sei mais porque eu ando com tanta coisa... mas a gente leva, vai que na hora precisa?”.

Assim vai crescendo a bolsa de professora. Enchem-se de objetos, remendos e histórias. Em dado momento, uma professora fala: "Se eu perder minha bolsa, as ideias não saem do lugar! Fico toda perdida!". Será que nessas bolsas de professoras se encontram os fios das linhas de fuga que nos conduzem para além dos planejamentos oficiais, previstos, pensados previamente? Que nos conduzem rumo as intensidades, multiplicidades, diferenças livres e nômades?

Talvez esse seja justamente o ponto. Talvez, aos modos deleuzianos (DELEUZE, 2011; DELEUZE; GUATARRI, 2014), bolsa de professora vire lugar de toda fabulação, onde os mundos vazem aos montes, onde toda a fundamentação faz remontar para além de todo fundamento o desfundamento (LAPOUJADE, 2015), a desterritorialização, onde o corpo é

\footnotetext{
${ }^{1}$ Para Michel de Certeau (1994), os usos dos artefatos são sempre da ordem das invenções cotidianas. Interfaces da Educ., Paranaíba, v.11, n.32, p. 135 - 158, 2020 
convidado a deixar o atual para tocar - ainda que de leve - as virtualidades da imanência.

Por isso nos colocamos em processo de criação com professoras e professores da rede de ensino do município de Vitória/ES no ano de 2019. Trabalhando a partir de redes de conversações (CARVALHO, 2009) tecidas com professoras de duas instituições de ensino ${ }^{2}$, apresentando os diálogos estabelecidos entre as professoras. As redes de conversações são, basicamente, encontros entre professoras. Inserimo-nos nas escolas por via dessas redes, colocando-nos a conversar com elas em momentos ditos "formativos" - isto é, em alguma formação realizada nas escolas, colocamos sempre temáticas que possam ser trabalhadas e dialogadas com as professoras, compondo, assim, uma tessitura de problemas e histórias oriundas de seus trabalhos. Justamente nisso consiste a rede de conversação: um duplo entre a produção de imagens dos cotidianos escolares a partir de colisões de ideias, afetos e políticas emergentes nas conversas e entre a partilha sensivel de modos de criar nas docências.

Perguntávamos como a bolsa da professora acaba por efetivamente se tornar material de criação de aula, fazendo coincidir, ainda que momentaneamente, a virtualidade com o atual. Afinal, o virtual nunca é independente das singularidades que o recortam e dividem-no no plano de imanência e, com isso, produzem-se sempre na própria relação da vida. A virtualidade se cria enquanto os corpos e os artefatos se entrelaçam. Assim, se a aula é da ordem do ensaio prolongado com breves momentos de invenção (DELEUZE; PARNET, 1996), a bolsa de professora parece ser justamente esse paradoxo de ensaio-invenção concentrado num único lugar.

Mas, afinal, o que é uma bolsa de professora? Como sabemos quando estamos diante de uma? E o que faz uma dessas bolsas? Como as bolsas se fazem lugar de criação numa sala de aula?

\footnotetext{
${ }^{2}$ Por uma questão ética e estética de escrita, optamos por manter as falas das professoras em um formato simples: itálico, espaçamento entrelinhas de 1,5 , sem apresentar o recuo tradicionalmente aplicado às citações longas, enfatizando a mesma força do texto acadêmico para que possa, assim, manter uma conversa direta com a própria escrita.
} 


\section{O que quer uma aula?}

Quando a sala de aula entra em cena, diferentes mundos se chocam. De imediato, uma professora em sala de aula tem pelo menos 10, 15, 20 mundos diferentes marcando presença e explodindo em pequenas supernovas. E, de algum modo, a expressão das vidas precisa colidir para que uma aula efetivamente possa acontecer. Não há aula em uma sala, mas aulas. E tanto mais aulas são dadas, quando mais corpos aparecem nesse espaço de guerra permanente.

Infinitos conhecimentos se conectam sempre de modo harmonioso e afrontoso ao mesmo tempo, criam intrigas onde o pensamento se aloja e condição paradoxal -, produz uma sensação afetiva quando se efetiva. Conhece-se por briga, por embate, ao se travarem disputas entre corpos. Uma aula é, em dada medida, uma guerra de mundos. Mas, afinal, o que quer uma aula?

Uma aula é marcada pela possibilidade de expandir os mundos, aumentar as redes de conhecimento de alunas e alunos. Como destaca Carlos Eduardo Ferraço ${ }^{3}$ (2008, p. 19), “[...] há diferentes possibilidades de conhecimento para os alunos que precisam ser consideradas e ampliadas". Nessa mesma direção, Nilda Alves e Regina Leite Garcia (2008), ressaltam que, durante o funcionamento da escola, acostumamo-nos a considerar os conflitos e as movimentações fatores que dificultam ou mesmo impedem a aprendizagem numa aula. Obviamente, trata-se de uma crítica com a qual compactuamos.

Se a escola tem como função o ensino - seja lá o que se quer ensinar! e se concordamos que uma sala de aula tende a ampliar os modos de enxergar e agir sobre o mundo, enxergar certo tipo de guerra como problema não condiz com nossa percepção de escola e de aula.

\footnotetext{
3 Ao longo do texto, a primeira aparição dos autores referenciados será sempre acompanhada de seu nome completo ou, pelo menos, de seu primeiro nome. Fazemos isso por uma questão política de enfrentamento à rigidez das ciências. Acreditamos que o uso dos nomes completos retira os autores de um caldeirão de anonimato e coloca-os mais próximos ao leitor.
} 
E, a partir da leitura radical do Comitê Invisivel (2016), a guerra é sempre entendida como parte fundamental à vida, como uma recusa à espera, à esperança. Entrar em guerra, para os autores, é permanecer em vida, lutar por sua existência, pela possibilidade de se expandir livremente. Como eles destacam, há um "asfixiante sentimento de impotência que esta organização social cultiva em cada um de nós" (COMITÊ INVISÍVEL, 2017, p. 18) que nos impele a um desejo de paz, outorgando de nós o direito de existirmos. Na lógica dos corpos em guerra, existimos afirmando nossas possibilidades de mundos. Não se trata, como eles anunciam, de uma guerra como morte. A guerra tem a ver com a ação, com a recusa à impotência, à paralisia. Guerreamos por não aceitarmos a passividade, a vida desligada de suas relações com o mundo.

Passividade seria da ordem de uma espera infinita. Esperariamos apenas que a vida acontecesse, que outros tornassem a vida mais bela, mais desejável. Recusando a lógica da paz e da espera, é preciso pensar e agir no tempo do agora, onde toda ação acaba por criar pequenos embates, pequenas colisões.

$\mathrm{Na}$ lógica da sala de aula, a vida é sempre no tempo presente. Não esperamos a aula acontecer sem que nós estejamos lá, de corpo presente, armados de boas ideias, de alunos ativamente envolvidos no trabalho peculiar que é vivido nas escolas. A aula é no agora, não amanhã, não ano que vem. Esperança vã daquela professora ou professor que imagina que o aluno aprenderá magicamente ou, ainda pior, do professor que sabe, desde o início do ano, que fulano e ciclano já estão reprovados. Agimos no tempo, sempre em luta. Planejamos justamente nossos embates. E mesmo planejada, a aula precisa guerrear entre os tempos, agir no presente contra o passado que nos prende, contra o futuro que nos impede de viver.

Guerrear implica abandonar o conceito de paraíso terrestre. Inúmeras vezes, a humanidade criou seus paraísos e, de algum modo, eles sempre se assemelham às prisões, aos hospitais ou aos sanatórios (COMITÊ INVISÍVEL, 2016). Não podemos fazer de uma sala de aula um paraíso. Optamos, antes, por fazer um campo de batalha. 
Como armas, carregamos nossas bolsas cheias de bugigangas. Nelas, levamos o passado com os quais podemos viver e não podemos esquecer, mas também os futuros que queremos criar.

Por isto, uma aula precisa que tudo saia do lugar desesperadamente. São mundos que se movimentam e se digladiam em uma aula. Movem-se sem sair do lugar, movem-se ao se expandirem, movem-se se misturando a outros que, até então, estavam em uma guerra de mil anos. Quando uma criança entra em contato com outra, toda uma cena de ações se desenrola ao infinito. Os movimentos de aproximação, de exploração do outro e de seus limites dizem de pequenos embates que produzem vidas coletivas. Esse é o ponto em uma sala de aula: as guerras, ainda que permanentes, não buscam o extermínio das vidas; antes, produzem modos de estar com o outro. São mundos que se expandem em direção ao infinito.

Uma aula implica um alto grau de afeto pela vida. Requer composição. Move-se por encontros, trocas, relações, grupalidades, coletividades.

Janete Magalhães Carvalho (2012), ao pontuar sobre os modos de efetivação dos currículos em uma escola, destaca haver sempre um conjunto de linhas traçado entre as pessoas envolvidas na ação escolar. Segundo ela, aprender é sempre da ordem de conseguir manter o corpo vivo, e, para tanto, mil contatos-contágios são necessários.

Contagiamo-nos justamente com as vidas que se colocam em embate conosco.

Na química, as colisões são o princípio da vida. Tudo se transforma a partir dos movimentos dessas colisões. A velocidade das reações aumenta, diminui, se multiplica ou mesmo interrompe com a simples finalidade de criação. Não se trata, de modo algum, de se estabilizar, mas de colidir para criar, para fazer acontecer a própria vida. A colisão química é criadora na medida em que faz arranjos entre átomos em infinitas moléculas e formas de vida.

Uma aula é, decerto, uma cadeia de colisões.

No sentido aqui abordado, uma aula pode ter muitos modos de acontecer, desde que o movimento dos afetos se faça presente de forma a Interfaces da Educ., Paranaíba, v.11, n.32, p. 135 - 158, 2020 
romper a hierarquia tradicionalmente imposta. Logo, a aula não impõe limites à vida, mas expõe e amplia suas dimensões. O conteúdo em si só se produz em importância quando todos os demais elementos colidem.

Mas onde a bolsa se localiza nessa aula?

A bolsa vaga entre os mundos. Não tem local, tem presença. A criação é sua própria atividade. Transitando, a bolsa de professora anseia por oportunidades. E elas não faltam! Porque uma sala de aula assume, para além do que os decretos e documentos afirmam sobre a educação, a vida como propósito de resistência.

Certa vez, levei para a sala um passarinho em uma gaiola. A intenção era conversar sobre as características dos pássaros e o cuidado com os animais, pois iriamos soltar o pássaro ao final da aula. Entretanto, nesse momento, uma criança de quatro anos começou a chorar muito e disse: "Tia, você não pode soltar esse pássaro! Ele não pode encontrar a sua mãe. Eu não encontro a minha mãe, então ele também não pode". Foi um momento muito difícil. Mudamos todo o planejamento da aula. Conversamos sobre o fato. Tomamos outros rumos. Começamos a falar das pessoas que amamos, sobre o que nos toca. Conversamos com os familiares da criança. Proporcionamos o encontro da criança com a mãe. Essa experiência nos atravessou.

Assim, somos lembrados justamente dessa riqueza de possibilidades de uma aula. E, como a professora nos conta, das aulas que são regadas de bolsas atemporais e cheias de vida. É vida em formato-pássaro, formatobaleia, formato-de-história quando as crianças transitam entre os mundos compossiveis com o que a bolsa carrega.

Uma aula, decididamente, não é uma bolsa e muito menos os apetrechos que ela carrega! Uma aula não é um livro, ainda que ele seja didático! Bolsa nenhuma faz aulas acontecerem, disso não temos dúvidas! Todavia, algo passa entre uma aula e uma bolsa. Quando uma professora abre sua bolsa e tira uma trambolhada de coisa dali, não são apenas os objetos que ele tira: são virtualidades, são multiplicidades de imagens. Quando a professora tira uma orca da bolsa e leva para suas crianças, ela carrega consigo um infinito de memórias que entrarão em jogo com os outros 
que compõem uma aula. As crianças entram no jogo com os artefatos junto aos professores e, naquele momento, tudo passa. Tudo delira na direção das invencionices. Como um professor afirma, se lhe pedissem para levar apenas um item indispensável dentro de sua bolsa, dentre todas as coisas, ele levaria um canivete suíço.

Curiosamente, nas mãos criadoras da docência, o canivete não tem função de corte, de defesa - antes, ele age sobre os mundos com as crianças. Mas em seu "uso" (CERTEAU, 1998), por vezes, depara-se com entraves, com forças que o obrigam a se preocupar com a função-corte do canivete, a função de autodefesa. As docências dançam entre o ato de criar e desgastes das políticas públicas.

\section{O pano rasgado de nossas bolsas}

Sempre levo um canivete suiço comigo, daqueles tipo chaveiro, pois sempre aparece um lápis que precisa ser apontado para o qual apontador nenhum dá jeito. Vez por outra precisamos cortar um papel, uma fita adesiva, um plástico e não tem tesoura por perto, tesoura boa, bem afiada e que por vezes carece ser usada como estilete para num zap fazer o recorte desejado. Ademais, há vezes em que alguma estrutura da sala - cadeira, mesa, quadro etc. - se solta e necessita de ter seus parafusos ajustados por uma chave de fenda, também presente no canivetinho. Eu mesmo, até já recoloquei a porta da minha sala certa vez. As crianças acham o máximo ter um professor tão precavido!

As bolsas não vêm ao centro dessa conversa para estigmatizar a professora ou o professor, pelo contrário, elas virtualizam, criam potencialidades, multiplicam-se em resistências para enfrentar novas guerras - talvez políticas. O professor que carrega o canivete suíço faz justamente alusões a esse embate político que a educação vivencia diariamente. É função dele fazer ajustes nas portas? Ser o responsável por apontar os lápis dos alunos? Nem de longe! Mas se não fizer, quem fará? O professor-canivete-suíço evidencia que, ao contrário do que falou Abraham Weintraub, o dito Ministro da Educação, não se trata de um processo de contingenciamento dos gastos na educação. Antes, falamos de 
desinvestimento. Aqui a lógica é evidente: vivenciamos uma falta de investimento processual na educação brasileira. E, por vezes, parecemos poder enfrentá-la apenas com nossas bolsas e as invenções criadas por meio dos artefatos culturais que carregamos nessas bolsas.

Mas como a barriga da bolsa confronta as políticas?

Não podem faltar duas coisas: minha garrafinha de água e minha bolsinha. Nela estão pendrive, lápis, borracha, canetas, tesoura, régua, cola, grampeador e outros... pois se não houver nenhum tipo de material disponivel para auxiliar, a minha bolsinha possui materiais básicos que me auxiliam em brincadeiras, nas atividades sistematizadas com as crianças, nas reuniões $e$ em outras ocasiões na escola.

É possivel que, com o governo Bolsonaro, a bolsa de professor ganhe ainda mais presença. Engorde. Mas em um sentido perigoso. Com a sobrecarga de peso, as bolsas rasgam, desgastam-se sendo arrastadas pelo chão. É difícil levantá-las. Devido aos cortes na educação, a ênfase destrutiva do modelo público passa a exigir de nós cada vez mais itens considerados básicos ao trabalho pedagógico, já que até o lápis, canetas, pincéis e apagadores passam a ser cotados como material de bolsas de professoras.

Aos poucos, nossas bolsas são sobrecarregadas não mais pelos mundos criadouros, mas por aquilo que exigem de nós em um nível quase doentio.

Sabe o que não pode faltar numa bolsa de professora? Caneta! Além de ser uma necessidade para as mais diversas situações, uma caneta na bolsa de uma professora é até mesmo uma pressão social!

Ora, é esse desinvestimento vivenciado hoje que nos torna reféns de nossas próprias possibilidades criadoras. Trabalhamos sempre em uma lógica de expansão dos afetos que compõem a vida e, reiteradamente, minam nossas invenções ao tirarem das escolas materiais infinitos.

Apesar de toda a precariedade a qual somos submetidos, ainda assim, fazemos baderna. A caneta pode ser uma pressão social em nossas bolsas, 
mas decididamente não é apenas para dar notas ou canetadas. Fazemos das canetas usos multicoloridos; nas mãos de uma criança, viram aviõezinhos, delineadores, máquinas de tatuagem. Há, sim, grande pressão social sobre nós e nossas bolsas tendem a pesar mais, mas não nos submetemos a lógicas únicas. O peso dentro delas pode carregar, inclusive, fantasias sexuais, desejos corporais, brincadeiras para além das escolas.

Damo-nos às lógicas irracionais e, com efeito, fazemos proliferarem situações indecorosas na qual vivemos a ordem do controle excessivo. Controlam-nos e, muitas vezes, não nos é possível reagir tal qual gostaríamos. Deveras, voamos baixo em seus radares. Carregamos conosco certas ousadias.

Em uma escola, uma professora emprestou um conjunto de tintas para uma colega e, logo em seguida, pediu para não jogar os potinhos fora quando acabasse. Prática comum, bem verdade. Vemos com frequência uma professora reencher os potes de tinta. Todavia, naquela cena, a tinta que ela usava para preencher era a tinta própria, comprada por ela para fazer o trabalho em questão. "Eu sou coordenadora também, então eu sei que nossas tintas estão acabando e temos o ano inteiro pela frente ainda", disse-nos ela.

$\mathrm{E}$, de algum modo, naturalizamos essa cena.

A boa professora não apenas carrega os mundos que gostaria de criar, como também os mundos que nos amarram - isto é, as lógicas em que nada podemos se não investirmos nós mesmos.

Assim, portanto, é preciso perguntar: como fazer invencionices quando as condições materiais da vida são tão rareadas? Como criar quando, em uma escola, falta até mesmo papel? Será que as invencionces, por se depararem com a lógica de faltas, são efetivamente minadas?

De antemão dizemos: é evidente que não. Ainda que a tinta nos falte, as tampas dos potinhos virarão jogos de xadrez, de jogo da velha, de damas; as beterrabas e a terra se transformam em tintas; os rabanetes viram carimbos; as caixas de papelão vazias virarão cenário de teatro, televisores, carrinhos, robôs. 
Justamente por isso nos temem tanto. Aprendemos a fazer a vida verter a partir de todas as mínimas vontades criadoras.

Talvez por isso lancem tantos papeis burocráticos para nós. Querem nos fazer usar as canetas a todo o custo. Justificam cada ato de burocracia a partir de suas infinitas prestações de contas: de materiais e de conhecimento. Tentam nos fazer prestar todos os serviços como se eles fossem, de algum modo, cabiveis de contenção. Exigem que registremos tudo para depois justificar cortes em gastos, limitar nossas ações, concentrar os recursos que podem nos enviar. Criam uma enorme gaiola de contenção ao redor da escola de modo a limitar a área de impacto das colisões.

$\mathrm{E}$ isso acontece, é claro, a cada canetada nova assinada por nossos governantes.

No dia 05 de novembro de 2019, foi anexada ao site do Senado Federal a Proposta de Emenda Constitucional n. 188, conhecida como PEC do "Pacto Federativo". Nas justificativas da PEC, o ministro Paulo Guedes e o presidente Jair Messias Bolsonaro apontam que os Estados e os Municípios "não têm liberdade na gestão de seus recursos", visto que "possuem, ainda, vinculações constitucionais para a despesa minima nas áreas de saúde e educação" (BRASIL, 2019, p. 18). Desse modo, devolver-se-ia "ao parlamento o protagonismo sobre decisões orçamentárias".

$\mathrm{Na}$ leitura do documento, o próprio site do Senado explica que a proposta da PEC seria uma conduta de combate à má gestão visando a descentralização dos recursos para os estados e os municípios. Hoje, por exemplo, há uma fixação de $25 \%$ do repasse das prefeituras sendo obrigatoriamente destinados à educação e $12 \%$ destinados à saúde. Sob a lógica desse documento, os gestores poderiam definir qual a quantia a ser destinada entre os dois, mantendo o percentual total de $37 \%$ intacto.

Logicamente, o problema é definir o que é mais importante.

No histórico das governanças brasileiras, sabemos que a educação tem sido alvo de desmonte contínuo. Há, obviamente, uma intensificação no governo atual. Tensionar, todavia, a educação e a saúde em uma tentativa de competição por recursos é deferir grau de importância maior para uma ou 
outra, quando, na verdade, essa não é e nem nunca foi a questão. Em casos extremos, justificar-se-ia o desinvestimento na educação por situações de calamidade pública como as ocorridas pelas enchentes ou queimadas anuais em algumas regiões do país. Nessa mesma moeda, no caso de contingenciamentos orçamentários - como o vivido por nós nesse ano -, o corte de um afetaria diretamente o outro, visto que eles comungam do mesmo balanço financeiro. Pelo viés interpretativo, a PEC ainda traz a problemática da desobrigação da construção de novas escolas públicas e do reajuste dos funcionários públicos.

Tradução: nossas bolsas têm se enchido cada vez mais com acessórios pedagógicos que, até então, esperávamos serem de obrigação pública. A partir do momento em que os limites de gastos disputam entre si, essa "obrigação pública" passa a ser mais e mais sucateada. Com efeito, o peso em nossos ombros aumenta. Agora são lápis que faltam às escolas, borrachas que nunca bastam, papéis que precisamos comprar em papelarias. A lista de compras de materiais das escolas nunca é o suficiente porque, a cada ano, chega menos verba para cada instituição. Viramos pedintes. Imploramos por doações de famílias, supermercados, papelarias; fazemos rifas para consertar máquinas de xérox, ventiladores, bebedouros. A verba é assídua em todas as academias - está sempre mais enxuta.

A bolsa aqui viram bolsas. Uma, duas, três, quatro bolsas são carregadas por cada professora. E quando pensamos que não, deixamos de lutar por nossos direitos para angariar mais uma bolsa. Que, por vezes, é uma bolsa financeira (bolsa alfabetização, bolsa família, bolsa estudo etc.).

$\mathrm{O}$ ataque ao setor público, desse modo, funciona como um golpe duplo a cada decreto assinado por nossos governantes.

Diante desses golpes, parecemos estar sempre necessitados de um kit s.o.s.

Se eu fosse dar um presente a uma colega professora para colocar na bolsa dela, eu daria um kit s.o.s. contendo revistinhas em quadrinhos, caçapalavras, alguns jogos tipo Uno, folhas, tesouras, colas e revistas. 
Sim, ao levar uma bolsa rasgada sobre os ombros ou pendurada em nossas mãos, é preciso que tenhamos clareza disso tudo. Seja puxando um carrinho ou contando com a ajuda de alunos para carregar o peso de nossas criações, rimos de nossas próprias rasgaduras. Apontamos as bolsas uns dos outros e criamos artes e remendos enquanto conversamos, trocamos ideias e traçamos novas virtualidades.

Resistimos.

\section{Bolsa, bolsa minha, existe algo dentro de sua barriga?}

Uma professora chega à escola carregando uma caixa de papelão toda pintada, duas folhas de E.V.A. enormes, duas sacolas cheias de fantoches de papel - criação dos alunos - e um livro escrito por ela mesma. Ela corre para a sala tão rápido quanto os materiais deixam-na correr. Baixinha, chama atenção por ser um monte de objeto andando pelos corredores. Chega atrasada, mas a turma nem liga. É dia da contação de história deles. A promessa é o próprio drama.

Uma breve aula de dramaturgia.

O que está por trás de tudo isso? Uma bolsa. Ou várias.

Essa é, decerto, a premissa da combinação entre aula e a bolsa de professora. Quando o rasgo do tecido não é tão visivel, as bolsas carregam pequenos mundos e permitem a reinvenção das histórias presentes em nossas vidas.

E os mundos, bem sabemos, são gerados nesses lugares mágicos que carregamos embaixo dos braços. As bolsas coladas em nossos corpos crescem infinitamente enquanto apostamos na vida, enquanto as abrimos às virtualidades.

A bolsa de professora é, com clareza, lugar de afetos e virtualidades.

David Lapoujade diz que um corpo é tão mais livre quanto mais atuais forem suas virtualidades. Especificamente, a "liberdade consiste em atualizar as virtualidades" (LAPOUJADE, 2017, p. 22).

Uma aula, enquanto um processo de criação e de ampliação das redes afetivas, age justamente sobre o atual do plano de imanência. Isto é, haveria, 
para Gilles Deleuze (2012), um plano da vida em que as forças estão já e sempre em jogo, em que o tempo se prolonga em um eterno agora, valendose ora da memória para manter-se em jogo, ora atualizando virtualidades que garantem sua existência. Esse plano do agora, o atual, seria justamente aquilo que está estabelecido, aquilo que age no mais imediato da vida nos mais diferentes e infinitos corpos, fossem eles humanos, vegetais, mecânicos, políticos, teóricos ou afetivos.

Porém, por agir nesse plano, a aula evoca forças que estão muito além e aquém do próprio atual. Ela se exercita no atual, obviamente. Todavia, para fazê-lo, traz elementos que figuram na memória coletiva da vida e nos sonhos de futuro que conseguimos produzir.

Isto é, uma aula vale-se do conceito de memória e de virtualidade para que, efetivamente, seja capaz de agir sobre os corpos.

E uma bolsa de professora carrega as virtualidades mais infinitas.

Mesmo um pouco descosturadas, as bolsas não se escondem. De longe é possivel identificá-las e, do nada, diversas mãos se unem às bolsas. Às vezes, devido à sobrecarga, para carregá-la; noutras, apenas por curiosidade e anseio. Em suma, afetos que a preenchem com total sentido, com vida. Quando uma aula e uma bolsa se encontram, expectativas são criadas. O plano do atual entra em rebuliço quando as bolsas se lançam à existência dentro de uma sala de aula.

A colisão, aqui, não é mais ao acaso como na química. Ela é o propósito.

Mas onde está a virtualidade de uma bolsa?

De modo básico: em tudo que ela carrega.

Cada objeto no interior de uma bolsa comporta mil virtualidades marcando todos os corpos que se encontram com eles. Um professor chega numa das escolas, certo dia, e topa com alguns dos seus alunos mexendo com uma lagarta. Uma lagarta comum, dessas simples. O professor, na mesma hora, lembrou-se de um objeto que tinha perdido em sua bolsa, algo bobo mas que, ao se encontrar com a lagarta, gerou uma muvuca sem fim: uma lupa de aumento. 
Após o encontro da lupa-lagarta, as crianças começaram a levar lagartas e outros insetos para a escola. A lupa esquecida no fundo da bolsa criou, ainda que momentaneamente, uma aventura científica. Não por coincidência, a turma trilhou para o estudo do reino animal, para as taxonomias e diferenciações entre os grupos de animais.

Eu nem lembrava da lupa dentro da bolsa, para ser honesto! Sabia que tinha colocado ela ali em algum momento para algum trabalho... mas sabe quando não dá tempo e você esquece? Tem um monte de coisas assim dentro da minha bolsa. Um monte! Mas ai deu certo. Uma lagarta virou quinze no outro dia, virou uma libélula no outro, vagalume, mosquito... e antes do fim da semana estávamos montando um trabalho sobre o reino animal!

Eis, justamente, o confronto entre os planos da vida.

O encontro lagarta-lupa ocorre no imediato, no plano do atual. Todavia, a intensificação das forças desse encontro leva a turma a um caminho inesperado. Isso é, decerto, a atualização do virtual. O virtual é, afinal de contas, "um conjunto de potencialidades indeterminadas, surdamente ativas, que agem como uma multiplicidade de tendências ainda implicadas umas nas outras" (LAPOUJADE, 2017, p. 23).

No encontro entre atual e virtual, "a atualização se faz por diferenciação, por linhas divergentes, e cria pelo seu movimento próprio outras tantas diferenciações de natureza" (DELEUZE, 2012, p. 36).

Isso é, em absoluto, o que a bolsa de professora faz: transforma ideias as mais variadas em objetos, em vida. Não interessa se é um objeto, uma planta, um animal, um texto - enfim, pouco importa o que ela carrega. Importa, ao contrário, as potencialidades daquilo que ela leva, o que pode ser discutido e criado a partir das experiências com esses corpos dentro da barriga da bolsa. São os artefatos que, manuseados por tão diferentes mundos, ganham vida e explodem as esferas limitrofes dos corpos.

Todo pequeno corpo dentro de uma bolsa colide infinitamente com os mundos e, a cada colisão, o corpo muda de natureza. Muda seu modo de estar no mundo e de afetá-lo. Assim a vida se dá a conhecer pelos corpos. Um corpo experimenta em cada parte de sua matéria - e de sua não-matéria 
- explosões intergalácticas quando entra em contato com virtualidades que, até então, ele não comportava. A mudança de natureza das coisas é justamente a possibilidade de agir diferentemente sobre toda a vida (DELEUZE, 2012). Os corpos dão-se a essas mudanças sempre que suas virtualidade são expandidas para além dos limites, quando são trespassadas por outros mundos.

Ah, eu tenho uma história boa pra contar sobre bolsas! Eu e uma amiga estávamos montando um trabalho juntos, ela professora do primeiro ano, eu do quarto. Ai a gente pediu um pedaço de pano à diretora. Ela arranjou pra gente, adorou a ideia. Dai levamos: um pano de 6 metros de comprimento por quase 4 de largura. E abrimos na quadra com alguns alunos das nossas turmas. Aí imagina. Aquelas crianças vendo aquele pano enorme lá, quase um tapete, e um grupo de crianças em cima desenhando. Uns desenharam, outros ajudaram a montar a trilha, outros pensaram nas ideias e nas armadilhas... fizemos um pedaço de algodão cru virar um daqueles jogos de caça-tesouro, sabe? Foi um trabalho que até as pessoas da minha familia ajudaram! E depois ainda usamos uma calça jeans velha para fazer uma bolsa para o tapete! Quando eu chego na sala com aquela bolsa de calça jeans, todos já sabem: é dia de caça-tesouro!

É possivel dizer que do encontro entre lupa-lagarta, canivete-lápisporta, gaiola-passarinho-mãe, tapete-bolsa-jeans, aulas são atravessadas por diferentes bolsas de professoras, onde a criação se manifesta frente às inúmeras existências.

Fazemos existências coloridas nas escolas. Imagine uma professora com sua caneta na bolsa, um bloco de post it multicolorido e toda a sua criatividade $e$ conhecimentos... poderia distribuir e deixar registrado por onde passar um pouquinho do seu saber. Seria uma rica partilha!

A coisa mais estranha que já levei para uma sala foram rolos de barbante. Pensei em uma proposta para trabalhar o movimento a partir de linhas, de acompanhá-las, traspassá-las... colocando por toda a sala de alto a baixo. Foi em uma oficina de dança. Foi uma experiência muito boa, o grupo se sentiu conectado pelas linhas. Há uma falta de conexão entre professores, falta 
sensibilidade com seus corpos e com os dos estudantes. Isso nos sensibilizou para pensarmos nossas relações no dia a dia.

Eis o óbvio: a bolsa quem cria é o professor, são as aulas, os mundos que ali colidem. A bolsa em seu aspecto mais singular é domínio criativo de todos os corpos que nela habitam - afetos, virtualidades. A potência de uma bolsa é tanto maior quanto por mais salas ela passar, quanto por mais mãos for tocada. Se não bastasse ser criativa, a bolsa faz graça das coisas que carrega, ri da infinidade de coisas inúteis que a alimenta. Às vezes, com o mais inesperado dos materiais, produz afetos inestimáveis com e entre os mais distintos mundos.

\section{O que não pode faltar numa bolsa de professora?}

Mas, afinal, o que carrega uma bolsa? Ou, como perguntamos às professoras e professores, o que não pode faltar numa bolsa? 


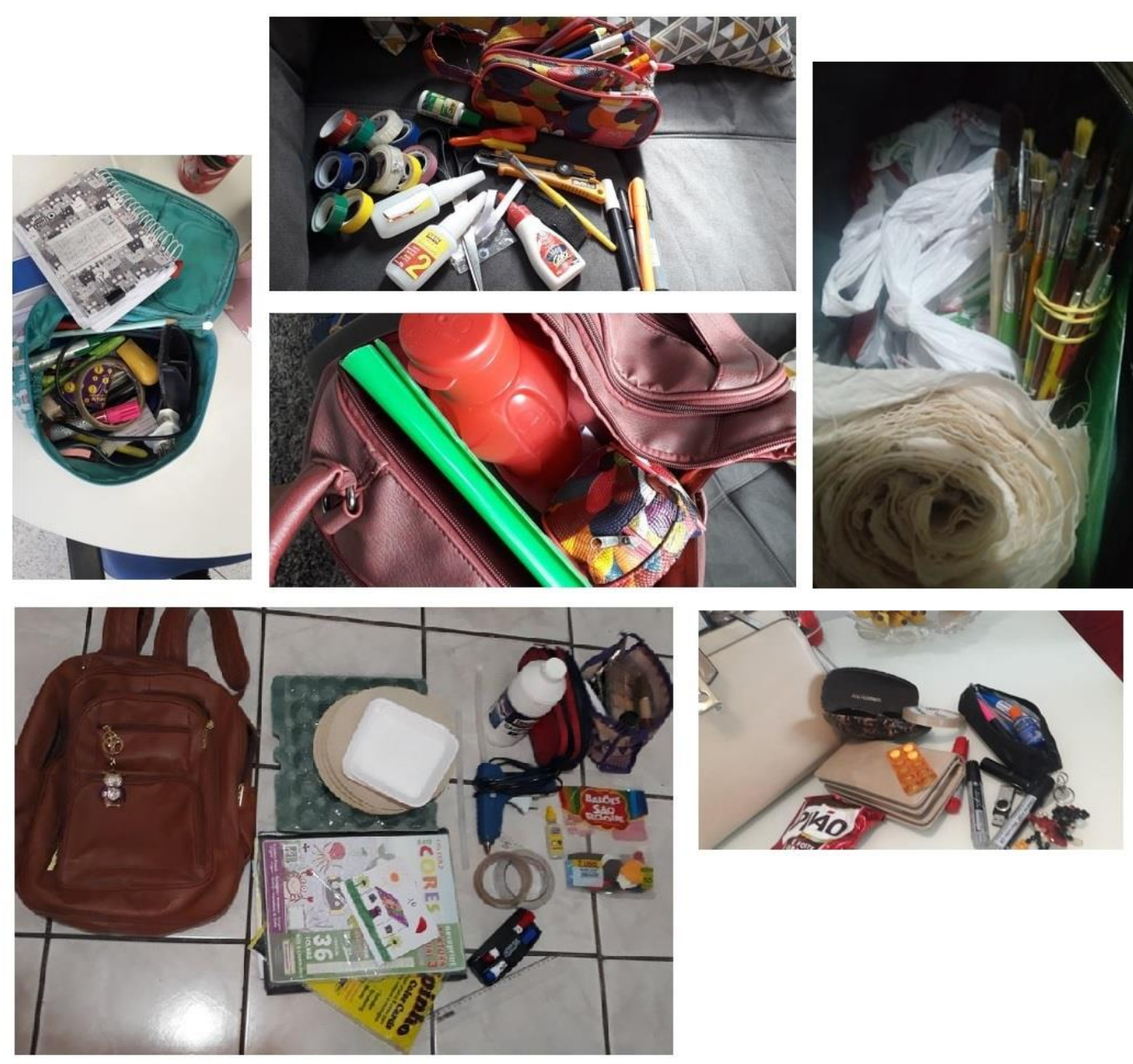

Figura 1 - O que não pode faltar numa bolsa de professora? Fonte: produção da pesquisa.

Dos sentidos mais diversos aos itens mais variados, o que não falta numa bolsa de professora é a possibilidade de criação. A caneta pretensamente considerada o item de mais comum em uma bolsa - casa harmoniosamente com as sapatilhas, com as agulhas. Uma professora, num dos momentos da rede de conversações, conta da experiência de desentupir a caneta com uma agulha. Outra professora entra na conversa e fala das vezes que remendou roupas dos alunos com linha e agulha.

De nossas bolsas, fazemos os pensamentos materializarem-se em desafios. Desafiamos a lógica estabelecida, desafiamos os afetos envolvidos numa sala de aula. E, por vezes, somos desafiados. 
Esses dias mesmo, meu aluno me desafiou. Cismou que goiaba não podia ser amarela, que era verde. Eu disse a ele que podia ser amarela TAMBÉM. Então ele me desafiou a levar goiaba amarela para a escola. Eu disse que levaria no outro dia e ele disse: "DUVIDO!" na minha cara. Então estávamos na biblioteca com ele fazendo prova e tinha outro [menino] que acompanho junto, me deixando P. da vida. E minha mochila lá do lado. Aí o outro menino falou algo, eu briguei e ele começou a rir. Aí eu, igual louca, já fui falando: "E você para de rir quando eu to brigando com Fulano senão eu vou pegar essa goiaba e jogar no lixo, hein?". A bibliotecária olhou com cara de "QUE QUE ISSO?", mas logo a gente começou a rir e comemos as goiabas. Que eram amarelas!

Assim nos relacionamos com nossas bolsas, com as aulas e com esses corpos que chamamos de alunos. Não há, em absoluto, uma lógica única a ser seguida. No inesperado da aula, a bolsa é convidada a dar continuidade às lógicas impensáveis, irracionais (LAPOUJADE, 2015).

Já cheguei a levar uma ossada de boi para a escola. Levei para simular fósseis quando representamos o calendário cósmico de Carl Sagan.

Após ler Rubem Alves falando sobre o professor de espantos, decidi me pôr a espantar meus alunos - e acabei espantando a mim e a eles. Busquei por coisas espantosas, curiosidades, experiências possiveis de serem efetivadas por crianças de 10 anos. Encontrei várias, mas sem dúvida a que mais espantou as crianças e a mim foi a experiência de cuspir fogo, com segurança e a partir de amido de milho. Me lembro de exclamar para mim mesmo antes de viver essa experiência pela primeira vez: "Aonde que Maizena pega fogo! Isso não pode ser verdade, nunca!". Foi puro jorro de vida, todas as crianças que quiseram, tiveram a oportunidade de viver a experiência de cuspir fogo. Tendo como único ônus a sensação de boca empapada causada pela mistura de amido de milho e saliva, acompanhada de um gosto estranho e nada agradável (só de escrever me veio à memória o gosto).

Mergulhados na dança entre aulas e bolsas, vemos a passagem da arqueologia à arte circense; entre bolsa e aula, vemos se efetuarem as mais 
estranhas combinações. As colisões que antes falávamos não ocorrem apenas entre crianças, entre alunos, mas também entre professores e suas próprias experimentações.

Se aula é da ordem do longo preparo para minutos de acontecimento ocasionais, as bolsas que carregamos fazem parte justamente dessa preparação. E, ainda assim, podem sempre nos surpreender. Há, afinal, como uma professora destaca, até mesmo a possibilidade de não ter bolsa. "Na minha bolsa não carrego nada. Nem carrego bolsa!".

Mesmo sem a materialidade da bolsa, entretanto, há bolsas plurais que habitam as invencionices das aulas.

\section{O peso de nossas bolsas}

A cena inicial volta: reconhecemos a professora por suas múltiplas bolsas. Isto é, estigmatizamos a figura da professora-cheia-de-bolsas. A professora que, para dar conta de toda a sua capacidade criadora, inventa mil e um apetrechos para carregar consigo por entre aulas, fazendo costuras entre a vida real em uma sala e as possibilidades que ela carrega em sua bolsa.

Sim, sabemos que a professora carrega o mundo em seus braços para dá-lo a explorar pelos corpos que se fazem alunos em suas passagens. Sim, sabemos que a professora luta, diariamente, contra as políticas que desinvestem diariamente na educação pública e que a forçam a aumentar sempre mais as bolsas e o peso sobre seus ombros. Sim, sabemos que as coisas que ela carrega dão vislumbres de mundos que, por vezes, são radicalmente desconhecidos pelos transeuntes desse espaço chamado sala de aula. Sim, sabemos que essa figura da professora-cheia-de-bolsas é, também, um perigo para as imagens de docência, para a naturalização da professora como quem faz tudo e mais o infinito para cumprir com os ideais de sociedade que vivemos.

Acostumamo-nos com a imagem de que uma boa professora é aquela que carrega, em seus ombros, um mundo inteiro de bugigangas prontas para dar vida a elas em suas criações-aula. E, decerto, não concordamos Interfaces da Educ., Paranaíba, v.11, n.32, p. 135 - 158, 2020 
com isso. Essa não pode ser a única imagem de professora que circula pela vida. Uma boa professora não é a professora-das-mil-e-uma-bolsas, mas a das mil e uma invenções. Não são as bugigangas e quinquilharias - antes, são as suas possibilidades criadouras.

Eu já levei eu mesma! Nosso projeto era sobre o mar. Alguns conteúdos versavam sobre caranguejo, preservação, valorização das pessoas $e$ profissionais ligados à pesca. Tive dificuldade de contatar um caranguejeiro para ser entrevistado. Então criei um personagem o Zeca Funé. Ele levou uma caixa (que meu pai preparou) com goiamum. Foi a única vez que o Zeca Funé apareceu.

Os professores des-fazem-se bolsas. Reconhecem a colisão de mundos que produzem no que há de mais extraordinário no educar e, automaticamente, colocam-se em criações na vida. Se uma aula pretende expandir mundos, as expansões só podem se fazer pelos limites da própria vida. Ainda que seja implodindo!

Explodimos em milhares de direções quando nos encontramos com outros corpos.

É o corpo que se expande para as bolsas que carregamos. É o corpo que inventa.

As invencionices, aprendemos, podem ser carregadas em um saco de pipoca de micro-ondas rasgado, em um bolso, na memória ou mesmo em silêncios. As invencionices atuam no limite entre o real imediato (o atual) e os reais possiveis (as virtualidades). "Isso vale para qualquer agenciamento concreto que se constrói no limite que pode fazê-lo oscilar, que o faz vibrar como uma pele de tambor, repetindo seu próprio fim em sua própria realização" (LAPOUJADE, 2015, p. 315).

Porque isso é a bolsa de professora, na verdade. Não o que ela carrega fisicamente, mas as virtualidades que ela tira de um espaço infinitesimal entre o corpo dela e o mundo. A bolsa de professora, como dizia uma colega, carrega - em sua máxima atividade - escutas e criatividades, escutas e invencionices. 
As bolsas são pesadas porque elas têm o peso do mundo que queremos criar. Podem, inclusive, ter o peso da leveza de um riso.

\section{Referências}

ALVES. Nilda; GARCIA, Regina Leite. (Orgs.). O sentido da escola. 5. ed. Petrópolis: DP et Alii, 2008.

BRASIL. Proposta de Emenda Constitucional n 188, de 2019. Senado Federal. Disponivel em: <https://legis.senado.leg.br/sdleggetter $/$ documento?dm $=8035501 \& \mathrm{ts}=1574981776862 \&$ disposition $=$ inline $>$. Acesso em: 01 dez. 2019.

CARVALHO, Janete Magalhães. O cotidiano como comunidade de afetos/afecções. Revista Teias, v. 13, n. 27, jan./abr., 2012, p. 75-87.

CARVALHO, Janete Magalhães. O cotidiano escolar como comunidade de afetos. Petrópolis: DP et Alii; Brasília: CNPq, 2009.

CERTEAU, Michel de. A invenção do cotidiano. Trad. Ephraim Ferreira Alves. 3. ed. Petrópolis: Vozes, 1998.

COMITÊ INVISÍVEL. Aos nossos amigos: crise e insurreição. Trad. Edições Baratas. São Paulo: n-1 edições, 2016.

COMITÊ INVISÍVEL. Motim e destruição agora. Trad. Vinicius Honesko. São Paulo: n-1 edições, 2017.

DELEUZE, Gilles. Bergsonismo. 2. ed. Trad. Luiz B. L. Orlandi. São Paulo: Ed. 34, 2012.

DELEUZE, Gilles. Critica e clínica. Trad. Peter Pál Pelbart. 2. ed. São Paulo: Ed. 34, 2011. 
DELEUZE, Gilles; GUATTARI, Félix. Kafka: por uma literatura menor. Trad. Cíntia Vieira da Silva. Belo Horizonte: Autêntica Editora, 2014.

DELEUZE, Gilles; PARNET, Claire. Abecedário de Gilles Deleuze. 1996. Disponivel em: <http://escolanomade.org/wp-content/downloads/deleuzeo-abecedario.pdf>. Acesso em: 02 dez. 2019.

FERRAÇO, Carlos Eduardo. Currículo, formação continuada de professores e cotidiano escolar: fragmentos de complexidade das redes vividas. In: FERRAÇO, Carlos Eduardo. (Org.). Cotidiano escolar, formação de professor(as) e curriculo. 2. ed. São Paulo: Cortez, 2008.

LAPOUJADE, David. Potências do tempo. Trad. Hortência Santos Lencastre. 2. ed. São Paulo: n-1 edições, 2017.

LAPOUJADE, David. Deleuze, os movimentos aberrantes. Trad. Laymert Garcia dos Santos. São Paulo: n-1 edições, 2015.

SENADO. PEC do Pacto Federativo descentraliza recursos para estados e municipios. Por: Milena Galdino. Publicado em: 11 nov. 2019. Disponível em: <https:/ /www12.senado.leg.br/noticias/materias/2019/11/11/pec-dopacto-federativo-descentraliza-recursos-para-estados-e-municipios>. Acesso em: 01 dez. 2019.. 